\title{
MOBILISASI WISATAWAN ASING TERHADAP POTENSI ANCAMAN NON TRADISIONAL DI INDONESIA
}

\author{
Laode Muhamad Fathun \\ Departemen Hubungan Internasional, Fakultas Ilmu Sosial \& Ilmu Politik, \\ Universitas Pembangunan Nasional Veteran Jakarta \\ E-mail:1m_fathun@yahoo.co.id
}

\begin{abstract}
This paper aims to explain the problem is getting the massive influx of foreign tourists to Indonesia. Massive foreign tourists to Indonesia appeared to have an impact on the potential threat of non-traditional Indonesia. The number of foreign travelers resulted by the government to capitalize on the object of the tourism industry as one of the country's foreign exchange objects. With the method of qualitative analysis supported by data collection techniques secondary and primary then produced the conclusion that the massive rating aving to Indonesia because of a) policies shaft maritime Jokowi as one of orientation is the development of the tourism industry, b) bilateral relations between Indonesia and a number of countries is getting more intense including in the field of pariwisatwa, trade, investment, energy, etc., c) the geopolitical posture especially Indonesian mainly sea access easier for foreign tourists to visit Indonesia, including the illegal way. The result is a policy response one BVK make many visits to Indonesia. The impact potentially against illegal behavior in the form of non tradisionaal threat of the emergence of illegal labor. This is related to the inability of the state to provide employment for its citizens but to take the labor of other countries. Thus, the policy of rating mobilization efforts should be supervised by all sides because of the potential not only to the emergence of foreign workers but other illegal behavior such as drug dealers.
\end{abstract}

Keywords: foreign tourists; mobilization; BVK; the potential threat; illegal Labor

\begin{abstract}
Abstrak
Kunjungan wisatawan asing secara besar-besaran ke Indonesia tampaknya berdampak pada potensi ancaman non-tradisional. Jumlah wisatawan asing yang dihasilkan oleh pemerintah untuk memanfaatkan objek dari industri pariwisata sebagai salah satu objek pendapatan negara. Tujuan dari penulisan artikel ini adalah untuk mengetahui dampak mobilisasi wisatawan asing terhadap potensi ancaman Indonesia. Dengan metode analisis kualitatif yang didukung oleh teknik pengumpulan data sekunder dan primer kemudian menghasilkan kesimpulan bahwa penilaian terhadapa wisatawan asing yang datang secara masif ke Indonesia karena a) Kebijakan poros maritim Jokowi sebagai salah satu orientasi pengembangan industri pariwisata, b) hubungan bilateral antara Indonesia dan sejumlah negara semakin gencar termasuk di bidang pariwisata, perdagangan, investasi, energi, dll., c) postur geopolitik khususnya Indonesia terutama akses laut lebih mudah bagi wisatawan asing untuk mengunjungi Indonesia, termasuk dengan cara ilegal. Hasilnya adalah respon kebijakan BVK dimana banyak wisatawan asing kunjungan ke Indonesia. Dampaknya berpotensi terhadap perilaku ilegal berupa ancaman non tradisional atas munculnya tenaga kerja ilegal. Hal ini terkait dengan ketidakmampuan negara untuk menyediakan lapangan kerja bagi warganya tetapi mengambil tenaga kerja dari negara lain. Dengan demikian, kebijakan upaya mobilisasi wisatawan asing harus diawasi oleh semua pihak karena berpotensi tidak memunculkan persoalan mengenai pekerja asing tetapi perilaku ilegal lainnya seperti pengedar narkoba atau kejahatan transnasional lainnya.
\end{abstract}

Kata kunci: wisatawan asing; mobilisasi; BVK; potensi ancaman; tenaga kerja illegal 


\section{PENDAHULUAN}

Mode pembangunan di zaman Jokowi lebih di arahkan pada pembangunan ekonomi sebagai fondasi nasional. Hal ini didasari pada karakter wholistic Jokowi dalam mengambil kebijakan sebagai mantan seorang pebisnis. Pola ini berpengaruh pula pada model kebijakan Jokowi sebagai pemimpin dan "manajer" Indonesia sampai tahun 2019. Arah kepemimpinan Jokowi lebih bersifat "ekonomi politik" di banding ketika SBY yang “ politik ekonomi". Ekonomi politik di maksudkan adalah pola pemerintahan yang dibentuk oleh Jokowi lebih dominan terkait dengan upaya kontrol ekonomi terhadap politik. Dalam arti segala sendi-sendi fondasi ekonomi harus di arahkan kembali sebagai upaya mendapatkan devisa negara (Fathun, 2016). Asumsi terjawab ketika Jokowi memprioritaskan sejumlah bidang-bidang "basah" sebagai fondasi ekonomi nasional. Hal itu berkaitan dengan (1) bidang energi, (2) pangan, (3) infrastruktur, (4) maritim dan (5) pariwisata. Dari kelima objek tersebut merupakan sejumlah bidang yang penting di bangun oleh Jokowi. Terkait dengan infrastruktur sebenarnya bukan objek pembangunan tetapi lebih berhubungan dengan pendukung dari empat objek lainya. Dari kelima bidang tersebut salah satu prioritas pemerintah adalah bidang pariwisata.

Pariwisata merupakan salah satu objek vital dalam membangun Indonesia. Hal ini didasari oleh keindahan alam yang dimiliki oleh Indonesia disertai dengan keanekaragaman budaya, etnik, bahasa, kuliner kerajinan tangan merupakan fondasi membangun Indonesia dalam bidang ekonomi kreatif. Mengapa dikatakan kreatif sebab hal ini berkaitan dengan inovasi yang di ciptakan oleh sejumlah daerah untuk menghasilkan pundi-pundi ekonomi tanpa harus mengeluarkan biaya mahal. Dalam arti bahwa hal ini berkaitan dengan tingkat kreatifitas dalam memanfaatkan budaya, kuliner, kondisi geografi daerah dan bidang lainya sebagai objek daya tarik wisatawan mancanegara. Hal inilah yang mendasari bahwa pembangunan pariwisata merupakan pembangunan yang strategis dalam fondasi ekonomi Indoensia, sebab sudah bisa dipastikan bahwa ketika wisatawan asing berkunjung ke Indonesia akan pula menikmati ekonomi kreatif ainya seperti kuliner, kerajinan, tarian dan lain-lain yang awalnya datang untuk berkunjung di daerah tersebut.

Munculnya kebijakan bebas visa asing (BVK) adalah intrumen respon kebijakan nasional di pemerintahan Jokowi berupa memberikan bebas visa kunjungan kepada sejumlah negara. Hal ini dilakukan untuk menarik sebanyak mungkin wiasatawan asing masuk ke Indonesia. Kebijakan strategis ini sebagai bentuk keseriusan Indonesia untuk menjadikan industri. pariwisata sebagai salah satu fondasi ekonomi nasional atau ekowisata. Upaya tersebut mulai di terbitkan Kepres tentang Bebas Visa Kunjungan 
Singkat,yang disempurnakan dengan Kepres tentang Bebas Visa Kunjungan. Diplomasi BSK memberikan kebijakan khusus untuk menarik minat sejumlah Negara melakukan kunjungan ekowisata di Indonesia yang terlihat dari jumlah Negara BSK dari 15 negara BVKS + 75 negara Bebas Visa Kunjungan (total 90 negara). Kemudian, diterbitkan Perpres No. 21 tahun 2016 tentang Bebas Visa Kunjungan Bebas visa bagi 169 negara. Dengan demikian bahwa sebagai salah satu tujuan negara pariwisata dunia maka penting bagi Indonesia menggunakan pariwisata sebagai instrumen mendapatkan devisa negara. Kebijakan strategis BVK merupakan bukti nyata keseriusan pemerintah membangun ekowisata sebagai salah satu fondasi ekonomi nasional.

Namun, lahirnya kebijakan tersebut bukan berarti tidak memiliki potensi tantangan dari eksternal Indonesia. Tantangan yang muncul berupa ancaman keamanan non tradisional Indonesia. Hal ini berhubungan dengan kecenderungan akan banyaknya kunjungan masal yang masuk di Indonesia yang bisa saja berpotensi membawa ancaman keamanan manusia seperti peredaran narkoba, masuknya tenaga kerja asing, aktifitas terorisme, dan imigran ilegal. Untuk itulah paper ini akan fokus pada ancaman tenaga kerja asing sebagai bagian dari ancaman non tradisional terhadap kedaulatan nasional Indonesia. Paper ini merupakan lanjutan hasil pemikiran penulis dari paper sebelumnya terkait diplomasi BVK dalam memaksimalkan industri pariwisata di Indonesia. Paper ini akan menjawab masalah mengapa Tenaga Kerja Asing semakin massif melakukan mobilisasi ke Indonesia, hipotesa ini menyangkut potensi ancaman terhadap angkatan kerja nasional. Dengan metode analisis kualitatif disertai teknik pengumpulan data sekunder dan primer diharapkan pemikiran ini bisa memberikan kontribusi akademik dan praktis terhadap preventif kebijakan nasional terkait industri wisata.

\section{PEMBAHASAN}

Isu pariwisata adalah salah satu isu yang menjadi instrumen negara untuk menarik devisa Negara dari tingkat kepuasan menikmati alam oleh pariwisata. Artinya negara tidak perlu berkontak fisik secara langung untuk meraih devisa negara, cukup dengan merawat sejumlah tempat destinasi sebagai objek penarik simpati wisatawan asing. Mengutip Renstra Kemenpar (Kementrian Pariwisata) dan data BPS pengembangan kepariwisataan difokuskan kepada 7 minat khusus, yaitu: (1) wisata budaya dan sejarah; (2) wisata alam dan ekowisata; (3) wisata olahraga rekreasi meliputi: menyelam, selancar, kapal layar, treking dan mendaki, golf, bersepeda, dan maraton; (4) wisata kapal pesiar; (5) wisata kuliner dan belanja; (6) wisata kesehatan dan kebugaran; dan (7) wisata konvensi, insentif, pameran dan event. 


\section{Jurnal Ilmu Sosial Vol. 16 | No. 2 | Edisi Juli - Desember 2017|Hal.94-111}

Pariwisata dan ekonomi kreatif memberikan kontribusi yang signifikan bagi perekonomian Indonesia. Dampak kepariwisataan terhadap Produk Domestik Bruto (PDB) nasional di tahun 2014 sebesar Rp. 391,49 triliun, 4,01\% dari PDB nasional.

Penciptaan PDB di sektor pariwisata terjadi melalui pengeluaran wisatawan nusantara, anggaran pariwisata pemerintah, pengeluaran wisatawan mancanegara, dan investasi pada usaha pariwisata yang meliputi: (1) Usaha daya tarik wisata; (2) Usaha kawasan pariwisata; (3) Jasa transportasi wisata; (4) Jasa perjalanan wisata; (5) Jasa makanan dan minuman; (6) Penyediaan akomodasi; (7) Penyelenggaraan kegiatan hiburan dan rekreasi; (8) Penyelenggaraan pertemuan, perjalanan insentif, konferensi dan pameran; (9) Jasa informasi pariwisata; (10) Jasa konsultan pariwisata; (11) Jasa pramuwisata; (12) Wisata tirta; dan (13) Spa. Di tahun 2014 ekonomi kreatif menciptakan nilai tambah sebesar Rp. 716,69 triliun, 7,06\% dari PDB nasional, melalui 14 subsektor industri kreatif, yaitu: Arsitektur; Desain; Fesyen; Film, Video, dan Fotografi; Kerajinan; Teknologi Informasi dan Piranti Lunak; Musik; Pasar Barang Seni; Penerbitan dan Percetakan; Periklanan; Permainan Interaktif; Riset dan Pengembangan; Seni Pertunjukan; dan Televisi dan Radio.

Kontribusi ekonomi kreatif ini belum memperhitungkan subsektor kuliner yang juga memiliki potensi tinggi. Sektor pariwisata dan ekonomi kreatif memiliki peran strategis dalam menciptakan nilai tambah bagi perekonomian nasional. Selain pencipta nilai tambah, sektor pariwisata dan ekonomi kreatif menyerap banyak tenaga kerja. Tahun 2014, dampak kepariwisataan terhadap penyerapan tenaga kerja sebesar 10,32 juta orang, 9,00\% dari tenaga kerja nasional. Di tahun yang sama, ekonomi kreatif menyerap 12, 30 juta tenaga kerja, 10,73\% dari total nasional. Strategi pro-poor dan pro-job sangat sesuai pada kedua sektor. Sektor pariwisata dan sektor ekonomi kreatif juga merupakan pencipta devisa yang tinggi. Tahun 2014 sektor pariwisata menciptakan devisa sebesar US\$ 11,17 miliar, meningkat dari US\$ 10,05 miliar di tahun 2013. Peningkatan penerimaan devisa di tahun 2014 tidak saja bersumber dari peningkatan jumlah wisatawan mancanegara dari 8,8 juta di tahun 2013 dan menjadi 9,44 juta ditahun 2014, tetapi bersumber dari peningkatan rata-rata pengeluaran perkunjungan dari US\$ 1.142,24 di tahun 2013, menjadi US\$ 1.183,43 di tahun 2014. Dengan kata lain, peningkatan kuantitas devisa kepariwisataan diikuti dengan peningkatan kualitas. Sementara itu, sektor ekonomi kreatif menyumbang ekspor yang jauh lebih tinggi dari nilai impornya. Ekonomi kreatif menciptakan devisa melalui kontribusi net trade, mencapai 5,90\% dari total nasional, atau senilai Rp 126,62 triliun di tahun 2014.

Mengutip Laporan Akuntabilitas Kementrian Pariwisata tahun 2015 menuliskan bahwa keadaan kepariwisataan Indonesia tahun 2015 secara makro menunjukkan 


\section{Jurnal Ilmu Sosial Vol. 16 | No. 2 | Edisi Juli - Desember 2017|Hal.94-111}

perkembangan dan kontribusi yang terus meningkat dan semakin signifikan terhadap PDB Indonesia sebesar 4,23\% atau senilai Rp. 461,36 triliun, dengan peningkatan devisa yang dihasilkan mencapai US\$ 11,9 milyar, dan tenaga kerja pariwisata sebanyak 12,16 juta orang. Pada kondisi mikro, juga ditandai dengan peningkatan jumlah wisatawan mancanegara (wisman) sebanyak 10,4 juta wisman dan wisatawan nusantara (wisnus) sebanyak 255,20 juta perjalanan. Disisi lain lain, salah satu indicator penting yaitu aspek daya saing kepariwisataan, berdasar penilaian WEF (World Economic Forum) posisi Indonesia juga meningkat signifikan dari ranking 70 dunia menjadi rangking 50 di tahun 2015. Pertumbuhan pariwisata Indonesia yang melebihi rata-rata dunia, sebagai mana tercatat di tahun 2015 sebesar 10,63\% memberikan kepercayaan diri Kementerian Pariwisata untuk meningkatkan target kunjungan wisman pada tahun 2016 dari 10 juta menjadi 12 juta.

Sementara itu, jumlah perjalanan wisatawan nusantara telah mencapai 255 juta perjalanan, Jumlah penyerapan tenaga kerja diperkirakan mencapai 11,3 juta orang. Tidak hanya itu, branding Wonderful Indonesia pada tahun 2015 naik 100 peringkat, dari semula tanpa peringkat menjadi peringkat ke-47, serta diraihnya berbagai penghargaan internasional untuk beberapa kategori, seperti; UNWTO Award 2015, ASEANTA Award 2015, World Halal Destination 2015.

Sektor pariwisata juga merupakan pencipta devisa yang tinggi. Tahun 2015 sektor pariwisata menciptakan devisa sebesar US\$11,9 miliar US\$ atau setara Rp163 trilliun (meningkat 113\% dibandingkan tahun 2014 yang mencapai angka devisa sebesar US\$11,17 miliar). Peningkatan penerimaan devisa di tahun 2015 tidak saja bersumber dari peningkatan jumlah wisatawan mancanegara dari 9,4 juta di tahun 2014 dan menjadi 10,4 juta di tahun 2015, tetapi juga bersumber dari peningkatan rata-rata pengeluaran per kunjungan dari US\$1.183,43 di tahun 2014, menjadi US\$1.190 di tahun 2015. Dengan kata lain, peningkatan kuantitas devisa kepariwisataan diikuti dengan peningkatan kualitas pengeluaran wisatawan.

Sedangkan data Kementrian Pariwisata dan Ekonomi Kreatif untuk tahun 2016 menunjukan bahwa wisatawan asing mencapai 12 juta orang dengan pendapatan nasional mencapai 172 triliun dan menyerap tenaga kerja sebanyak 11,7 juta orang. Sedangkan target Kementrian Pariwisata dan Ekonomi Kreatif pada 2019 ingin mencapai masuknya wisatawan asing sebanyak 20 juta orang disertai dengan tingkat pendapatan nasional sebesar 240 triliun yang akan menyerap tenaga kerja sebanyak 13 juta orang. Hal ini juga membuat Kementrian Pariwisata dan Ekonomi Kreatif berupa auntuk menaikan tingkat kompetitif Indonesia menjadi 30 dari urutan 50. Dengan demikian bahwa pentingnya ekonomi wisata adalah menjadi prospek yang potensial untuk membangun Indonesia. Hal ini pual sesuai dengan arahan presiden pada 15 Juni 2015 dalam Rencana Kerja Pemerintah /RKP Tahun 2016. Oleh 


\section{Jurnal Ilmu Sosial Vol. 16 | No. 2 | Edisi Juli - Desember 2017| Hal.94-111}

sebab itulah, dengan BVK merupakan salah satu instrumen pemerintah dalam menaikan angka kunjungan wisatawan asing ke Indonesia.

\section{Kebijakan Bebas Visa Asing}

Upaya pengelolaan sektor industri pariwisata Indonesia merupakan kebijakan yang strategis. Hal ini bukan hanya berhubungan dengan tingkat pendapatan yang dihasilkan dari industri pariwisata tersebut akan tetapi image yang di bentuk sebagai negara tujuan wisata harus meningkat setiap tahunnya. Tentu hal tersebut berkaitan dengan gengsi Indonesia yang sudah diketahui dunia akan potensi alamnya namun tidak didasari dengan tingkat kompetitif yang baik dalam ukuran global. Ada banyak faktor yang bisa mempengaruhi hal tersebut salah satunya adalah kecenderungan untuk prioritas kebijakan dalam merespon kebutuhan wisata nasional maupun tujuan wisata internasional. Untuk itulah kebijakan -kebijakan yang dibentuk saat ini merupakan konstruksi yang menunjukan upaya pemerintah serius menggarap potensi wisata sebagai salah satu tonggak membangun ekonomi nasional.

Hal ini tertuang dalam arahan presiden pada desember 2014 yang menyatakan bahwa industri pariwisata merupakan cara yang paling cepat untuk mendatangkan devisa apabila promosi dan pembangunan jaringan dikelola dengan baik. Pariwisata dapat ditingkatkan secara cepat apabila aspek promosi dikelola dengan baik dan benar (Asvaliantina, 2016). Dukungan kebijakan tersebut adalah bukti kongkrit keseriusan Jokowi membangun industri wisata sebagai salah satu aset nasional.

BVK adalah membuat instrumen kebijakan yang secara internasional atau memberikan hak istimewa kepada 169 negara di dunia untuk berwisata ke Indonesia dengan bebas visa kunjungan dalam tempo tertentu. Hal ini didasari oleh Kepres No. 15 tahun 1983 tentang Kebijakan Pengembangan Kepariwisataan sebagaimana telah dirubah dengan Kepres No. 39 tahun 1986, kebijakan tersebut pada dasarnya mengisyaratkan bahwa seluruh wisatawan asing harus bebas visa. Setelah itu, Kepres No. 18 tahun 2003 tentang Bebas Visa Kunjungan Singkat, yang telah direvisi menjadi Peraturan Presiden No. 43 tahun 2011. Bebas Visa Kunjungan hanya bagi 15 Negara Mulai diberlakukan Visa kunjungan saat kedatangan/VOA. Kemudian, Kepres No. 69 Tahun 2015 tentang Bebas Visa Kunjungan, yang telah direvisi menjadi Kepres No. 104 tahun 201515 negara BVKS + 75 negara Bebas Visa Kunjungan (total 90 negara) (Okto Haryant,2016:29). Setelah itu, diterbitkan Perpres No. 21 tahun 2016 tentang Bebas Visa Kunjungan Bebas visa bagi 169 negara. Dalam website Ditjen Imigrasi RI mengisyaratkan ada dua hal yang harus di miliki oleh wisatawan asing yang termasuk dalam 169 negara tersebut apabila ingin berkunjung yakni: a) Memiliki Paspor dengan masa berlaku paling singkat 6 (enam) bulan , b) Memiliki tiket kembali atau 


\section{Jurnal Ilmu Sosial Vol. 16 | No. 2 | Edisi Juli - Desember 2017|Hal.94-111}

kedatangan/VOA. Kemudian, Kepres No. 69 Tahun 2015 tentang Bebas Visa Kunjungan, yang telah direvisi menjadi Kepres No. 104 tahun 201515 negara BVKS + 75 negara Bebas Visa Kunjungan (total 90 negara) (Okto Haryant,2016:29). Setelah itu, diterbitkan Perpres No. 21 tahun 2016 tentang Bebas Visa Kunjungan Bebas visa bagi 169 negara. Dalam website Ditjen Imigrasi RI mengisyaratkan ada dua hal yang harus di miliki oleh wisatawan asing yang termasuk dalam 169 negara tersebut apabila ingin berkunjung yakni: a) Memiliki Paspor dengan masa berlaku paling singkat 6 (enam) bulan , b) Memiliki tiket kembali atau tiket untuk melanjutkan perjalanan ke negara lain. Dalam konteks inilah terlihat jelas upaya internasionalisasi Indonesia melalui kebijakan BVK untuk memperluas jaringan masuknya wisatwan asing untuk mengejar target yakni 20 juta pengunjung sampai 2019.

\section{Kebijakan Mobilisasi Wisatawan Asing Dalam Kepentingan Indonesia}

Mengapa masih sangat masif masuknya wisatawan asing ke Indonesia? Menurut penulis dipengaruhi beberapa hal berikut: pertama, Indonesia sedang fokus pada kebijakan poros maritim dimana salah satu agenda dari kebijakan tersebut adalah terkait dengan pengelolaan pariwisata Indonesia. Indonesia yang dikenal sebagai Negara yang memiliki ke indah alamnya jadi tools ekonomi politik untuk menarik masuknya wisatawan asing ke Indoneia. Tidak main-main target pemerintah ingin mendapatkan 20 juta pengunjung wisata pada tahun 2019. Hal ini menurut pemerintah masih di rasa sangat kurang jika di bandingkan dengan Negara tetangga seperti Thailand dan Malaysia. Dalam konteks inuilah konsep ekonomi wisata menjadi intrumen pemerintah untuk meenjadikan pariwisata sebagai salah satu fondasi ekonomi nasional. Faktanya dalam arahan Presiden 15 Juni 2015, Rencana Kerja Pemerintah/RKP Tahun 2016, Pariwisata merupakan sektor yang paling cepat meningkatkan pertumbuhan ekonomi. Pemerintah harus all out dalam industri pariwisata. Industri pariwisata merupakan cara yang paling cepat untuk mendatangkan devisa apabila promosi dan pembangunan jaringan dikelola dengan baik.

Pariwisata dapat ditingkatkan secara cepat apabila aspek promosi dikelola dengan baik dan benar. Dalam Arahan tanggal 24 Juni 2015, Pokok Bahasan: Masalah Pariwisata, Paket destinasi dan produk pariwisata yang belum menarik agar segera diperbaiki. Tempattempat pariwisata yang sudah ada, tetapi belum laku, perlu ada perbaikan dan ditingkatkan promosinya. Kemudian, Arahan Presiden 15 Oktober 2015, diperlukan sebuah langkah nyata lapangan, sehingga 10 destinasi wisata tersebut benar-benar dapat terlihat perubahan, baik perubahan di bidang lingkungan, penataan pedagang, perbaikan manajemen promosi daerah, dan perbaikan infrastruktur, terutama air bersih, listrik, jalan dan kamar mandi (Kutipan arahan Presiden ketika penulis menjadi presenter dalam Konfrensi Nasional terkait maritim di Yogyakarta, 2016 Oleh Kementrian Koordinator Bidang Maritim dan Pushankam UPN 


\section{Jurnal Ilmu Sosial Vol. 16 | No. 2 | Edisi Juli - Desember 2017|Hal.94-111}

di Yogyakarta, 2016 Oleh Kementrian Koordinator Bidang Maritim dan Pushankam UPN Veteran Yogyakarta).

Seperti yang telah di jelaskan di atau bahwa upaya tersebut adalah untuk memaksimalkan kegiatan traveling yang dilakukan oleh wisatawan asing yang dikatakan oleh Mc Intosh yaitu a) Pleasure ,b) Relaxation, rest and recreation,c) Health, d) Participation in sports, e) Curiousity and culture, f) Ethnic and family, g) Spiritual and Religious, i) Status and prestige, j) Professional or business. Dari kegiatan tersebut kebanyakan terjadi di Indonesaia. Makanya dalam Renstra pengembangan kepariwisataan difokuskan kepada 7 minat khusus, yaitu: (1) wisata budaya dan sejarah; (2) wisata alam dan ekowisata; (3) wisata olahraga rekreasi meliputi: menyelam, selancar, kapal layar, treking dan mendaki, golf, bersepeda, dan maraton; (4) wisata kapal pesiar; (5) wisata kuliner dan belanja; (6) wisata kesehatan dan kebugaran; dan (7) wisata konvensi, insentif, pameran dan event.

Tidak main-main ekowisata menyumbang Produk Domestik Bruto (PDB) nasional di tahun 2014 sebesar Rp391,49 triliun, 4,01\% dari PDB nasional.pada 2015 yang terus meningkat dan semakin signifikan terhadap PDB Indonesia sebesar 4,23\% atau senilai Rp461,36 triliun dan 2016 orang dengan pendapatan nasional mencapai 172 triliun. Tidak hanya itu, branding Wonderful Indonesia pada tahun 2015 naik 100 peringkat, dari semula tanpa peringkat menjadi peringkat ke-47, serta diraihnya berbagai penghargaan internasional untuk beberapa kategori, seperti; UNWTO Award 2015, ASEANTA Award 2015, World Halal Destination 2015. Hal inilah yang dikatakan Latupapua (2008) bahwa Ekowista merupakan konsep dan istilah yang menghubungkan pariwisata dengan konservasi, ekowisata sering dipahami sebagai pariwisata berwawasan lingkungan, jenis wisata ini merupakan salah bentuk pariwisata alternatif yang menonjolkan tanggungjawab terhadap lingkungan.

Faktual yang lain adalah Pemerintah sudah fokus dalam pengembangan sektor pariwisata Special Economic Zones (Paket Kebijakan Ekonomi ke-6) yaitu Tanjung Lesung, Mandalika dan Morotai sebagai tourism. Penurunan tarif pajak konstruksi dalam sektor pariwisata Kebijakan Kebijakan Bebas Visa Kunjungan Singkat (BVKS) ke hampir 200 negara bahkan telah dibuat Program 10 "Bali Baru" yaitu Danau Toba (Sumatera Utara), Tanjung Kelayang (Bangka Belitung), Tanjung Lesung (Banten), Kepulauan Seribu (DKI Jakarta), Candi Borobudur (Jawa Tengah), Gunung Bromo \& Gunung Semeru (Jawa Timur), Labuan Bajo (Nusa Tenggara Timur), Mandalika (Nusa Tenggara Barat), Wakatobi (Sulawesi Tenggara), dan Morotai (Maluku Utara). Dengan faktual itulah pariwisata di 


\section{Jurnal Ilmu Sosial Vol. 16 | No. 2 | Edisi Juli - Desember 2017|Hal.94-111}

jadikan pemerintah Indonesia sebagai instrumen kepentingan diplomasi Indonesia melalui diplomasi budaya, kuliner, batik, kesenian, dll. Hal ini merupakan bentuk softpower Indonesia dalam mencapai kepentingannya dalam memperluas koneksi kerjasama non teknik, pertambangan, dll.

Alasan kedua adalah makin meningkatnya hubungan bilateral Indonesia baik dengan Negara-negara Asia Pasifik maupun regiona lainnya. BVK membuat instrument kebijakan yang secara internasional atau memberikan hak istimewa kepada 169 negara di dunia untuk berwisata ke Indonesia dengan bebas visa kunjungan dalam tempo tertentu. BVK bukan hanya membuka peluang hubungan bilateral dalam bentuk kunjungan wisata namun menjadi bagian dari first track diplomacy Indonesia. Langkah ini berupa respon kebijakan khusus kepada 169 negara yang akan di tingkatkan menjadi 200 negara adalah langkah awal dalam memancing minat bukan hanya untuk berkunjung tetapi berinvestasi di bidang pariwisata dan bidang lainya. Artinya setelah langkah ini ada second track diplomacy Indonesia dalam menjaring minat donor luar negeri untuk menjalin hubungan luar negeri. Hal ini terbukti dengan kerjasama pariwisata antar Indonesia dan Italia. Dikutip dari metrotvnews.com memberitakan bahwa Indonesia telah melakukan penandatangan MoU di bidang pengembangan pariwisata. Menurut Menteri Pariwisata Arief Yahya mengatakan bahwa Indonesia telah membuka 10 destinasi unggulan yang hendak dibangun sebagai kawasan strategis pariwisata dan kawasan ekonomi khusus pariwisata.

Ada lima poin di MoU Indonesia-Italia yaitu, Pertama, kerjasama di bidang pemasaran dan promosi pariwisata, di forum pameran internasional kedua negara. Kedua, kerjasama pengembangan produk, riset, kajian, dan promosi bersama, baik destinasi konvensional maupun non konvensional. Ketiga, kerjasama informasi dan publikasi, pertukaran bahan brosur, bahan pameran, film, foto di bidang pariwisata. Keempat, pengembangan SDM. Kelima, mendukung kerjasama antarindustri pariwisata dari kedua Negara. Bukan hanya dengan Itali namun ada juga Singapura yang melakukan hubungan bilateral dalam bidang ini yang telah melakukan penandatangan MoU. Di beritakan dari detikTravel.com bahwa Indonesia dan Singapura telah melakukan $\mathrm{MoU}$ on Tourism Indonesia - Singapore di selasela Leader's Retreat, di Semarang. MoU mengatur hubungan bilateral menyangkut terutama soal promosi dan pemasaran bersama kapal pesiar (cruise) dan Meetings, Incentives, Conferences, Exhibitions (MICE). Kegiatan lain yang dapat dilakukan adalah pembangunan destinasi dan pelabuhan, pengembangan sumber daya manusia melalui pelatihan, seminar, lokakarya, penelitian, pengembangan investasi pariwisata, kerja sama sektor swasta dan pertukaran informasi. Ada beberapa negara lagi yang melakukan hubungan bilateral dengan Indonesia misalnya Tiongkok, dan Vietnam. 


\section{Jurnal Ilmu Sosial Vol. 16 | No. 2 | Edisi Juli - Desember 2017| Hal.94-111}

Namun perlu ditegaskan bahwa second track diplomacy belum cukup menjadikan pariwisata untuk menarik investasi namun membutuhkan pula public diplomacy. Public Diplomacy menyangkut multitrack diplomacy adalah metode diplomasi dengan multi jalur. Dalam hal inilah terkait dengan promosi, penyebaran, penjualan berhubungan dengan aktor selain negara dalam model diplomasi. Aktor seperti Akademisi, pebisnis, NGO, Tokoh agama dan lain-lain merupakan instrumen yang bisa dikembangkan sebagai sarana diplomasi Indonesia diluar negeri.

Alasan ketiga adalah berhubungan dengan postur geopolitik Indonesia. Postur Indonesia sebagai negara kepulauan memungkinkan banyaknya wisatawan asing masuk ke Indonesia karena tidak ingin ingin repot mengurus visa. Posisi Indonesia yang terdiri atas pulau-pulau memungkinkan rawan terjadinya mobilisasi orang asing masuk ke Indonesia. Hal ini terbukti dengan adanya travel agen yang menggunakan hal tersebut sebagai potensi bisnis yang menggiurkan. Jadi ada kemungkinan bahwa para wisatawan yang datang untuk berlibur bisa disalahgunakan untuk masuk bekerja ke Indonesia akibat dari BVK. Dikutip dari laman Ditjen Imigrasi RI , Kepala Kantor Imigrasi Kelas I Khusus Surabaya Zaeroji mengatakan bahwa ada agen-agen travel yang mengurusi dokumen warga negara asing (WNA). Pasalnya, banyak WNA yang selalu bermasalah dan terpaksa berurusan dengan kantor imigrasi. WNA menggunakan jasa agensi untuk mengurus semua dokumen. Antara lain, paspor, visa, izin mempekerjakan tenaga kerja asing(imta), dan sponsor. Masalahnya, banyak agensi yang sulit mengurus karena ada dokumen WNA yang kurang. Realitas inilah menjadi salah satu tingkat kerawanan potensi ancaman terhadap masuknya tenaga kerja asing selain dari postur geopolitik Indonesia. Akibatnya dengan paspor visa wisata disalah gunakan untuk bekerja di Indonesia tanpa melakukan laporan ke pihak imigrasi.

\section{Ancaman Masuknya Tenaga Kerja Asing}

Letak geografi Indonesia yang luas dengan jumlah penduduk yang mencapai 250 juta orang lebih ternyata tidak sejalan dengan lapangan pekerjaan yang tersedia. Dengan komposisi penduduk yang banyak seharusnya penyediaan lapagan kerja di Indonesia harus memadai. Tujuan kongkritnya adalah untuk meminimalisir dampak munculnya pengangguran yang merajalela yang cenderung bisa saja memicu konflik sosial dan prilaku kriminal di masyarakat. Dengan tingkat kestabilan ekonomi mencapai 5 persen lebih pada ekonomi makro Indonesia masih belum maksimal dalam meminimalisir terjadinya pengguran di dalam negeri.

Mengutip data BPS bahwa Tingkat Pengangguran Terbuka (TPT) Februari 2015 sebesar 5,81 persen menurun dibanding TPT Agustus 2014 (5,94 persen), dan meningkat dibandingkan TPT Februari 2014 (5,70 persen). Selain itu, (Februari 2014-Februari 2015) 
kenaikan penyerapan tenaga kerja terjadi terutama di Sektor Industri sebanyak 1,0 juta orang (6,43 persen), Sektor Jasa Kemasyarakatan sebanyak 930 ribu orang (5,03 persen), dan Sektor Perdagangan sebanyak 840 ribu orang (3,25 persen). Pada Februari 2015, penduduk bekerja masih didominasi oleh mereka yang berpendidikan SD ke bawah sebesar 45,19 persen, sementara penduduk bekerja dengan pendidikan Sarjana ke atas hanya sebesar 8,29 persen.

Pada Agustus 2016, jumlah angkatan kerja sebesar 125,44 juta orang naik sebanyak 3,06 juta orang dibandingkan Agustus 2015. Jumlah penduduk bekerja meningkat sebanyak 3,59 juta orang. Jumlah pengangguran turun sebanyak 530 ribu orang. TPT mengalami penurunan sebesar 0,57 persen poin. Jumlah penduduk yang bekerja turun sebanyak 200 ribu orang. Penurunan ini terutama terjadi di Sektor Pertanian, sedangkan Sektor Perdagangan mengalami peningkatan jumlah penduduk yang bekerja. Jumlah pengangguran turun sebanyak 430 ribu orang. Secara makro ekonomi dan PDB Indonesia juga meningkat namun sepertinya tidak secara mikro atau senyatanya. Hal ini masih terlihat jumlah pengguran yang besar terutama di kota besar. Kesulitan untuk mendapatkan pekerjaan bukan hanya di alami oleh orang yang memiliki pendidikan rendah bahkan tingkat kompetisi sarjana dan ketersediaan lapangan kerja tidak sebanding dengan lulusan dari ribuan perguruan tinggi di Indonesia.

Inilah yang menjadi problems di saat kondisi internal saja masih kesulitan dalam menciptakan ketersediaan lapangan kerja, justru ancaman tenaga kerja asing berdatangan ke Indonesia. Hal ini menjadi salah satu dampak dari kebijakan bebas visa asing yang diterapkan oleh pemerintah untuk memaksimalkan potensi pariwisata sebagai akses untuk mendapatkan devisa Negara. Kebijakan strategis BVK memang sangat potensial namun tidak bisa dipungkiri juga bahwa ada banyak keuntungan yang didapat oleh sejumlah oknum terkait dengan munculnya kebijakan itu. Misalnya para agen perjalanan yang tidak terlalu detail memeriksa para travelernya, belum lagi prilaku korup sejumlah petugas terutama daerah perbatasan.

Terkait kebijakan BVK menjadi ontologi membanjirnya kunjungan wisatawan asing ke Indonesia. Dampaknya jelas adalah pada ketersediaan lapangan kerja, sebab dalam beberapa kasus dengan menggunakan paspor wisata beberapa wisatawan menggunakan celah tersebut untuk bekerja di Indonesia. Memperkuat pernyataan penulis, mengutip Ronny Sompie, Direktur Jenderal Imigrasi,dikutip dari laman berita Ditjen Imigrasi RI, bahwa Pemberian fasilitas bebas visa wisatawan asal 30 negara oleh pemerintah meningkatkan jumlah warga negara asing yang masuk ke Indonesia. Pada Juni-Agustus 2015 terdapat 864.982 orang 
warga negara asing masuk ke Indonesia. Padahal, pada periode yang sama tahun sebelumnya hanya terdapat 740.718 orang warga negara asing yang masuk ke dalam negeri. Itu artinya pada Juni-Agustus 2015 ada kenaikan warga negara asing yang masuk ke Indonesia hingga 124.264 orang dibandingkan dengan periode yang sama tahun sebelumnya.

Dikutip dari Detiknews, menurut Mentri Hanif Dhakiri bahwa TKA yang masuk ke Indonesia dari 2011 sampai 2015. Pada 2011 jumlah TKA sebanyak 77.307 orang, di 2012 sebanyak 72.427 orang, di 2013 sebanyak 68.957 orang, di 201468.762 orang, di 2015 sebanyak 69.025 orang. Adapun negara-negara yang warganya bekerja di dalam negeri yaitu menurut data Kementerian Tenaga Kerja dan Transmigrasi menunjukkan bahwa pekerja asal Negeri Jepang periode Januari-November 2016 mencapai 12.490 orang atau sekitar 16,8 persen dari total TKA yang terdaftar di Indonesia sebanyak 74.183 pekerja. TKA asal Cina merupakan yang terbesar, yaitu berjumlah 21.271 pekerja atau sekitar 28,7 persen. Adapun TKA asal Korea Selatan menjadi yang terbesar ketiga dengan jumlah 8.424 pekerja atau sekitar 11.4 persen. Jumlah TKA dari Singapura mencatat kenaikan tertinggi sepanjang 2016, yaitu sebesar 40 persen menjadi 1.748 pekerja. Adapun jumlah tenaga kerja asing dari Thailand menurun paling besar sebesar 32,7 persen menjadi 2.394 pekerja.Jumlah tenaga kerja asing (TKA) yang berada di Indonesia hingga November 2016 mencapai 74.183 pekerja meningkat 7,5 persen dari posisi akhir 2015, yaitu 69.025 pekerja. Rata-rata tenaga kerja asing di Indonesia periode 2011-2016 mencapai 71.776 pekerja.

Dalam KOMPAS.com, Direktur Jenderal Imigrasi Kementerian Hukum dan HAM, Ronny F Sompie mengatakan, berdasarkan data yang tersebar dari 125 kantor imigrasi dan 131 tempat pemeriksaan imigrasi di Indonesia sejak Januari hingga 18 Desember 2016, WNA yang datang ke Indonesia mencapai 8.974.141 orang. Ronny menyebutkan, dari jumlah 8,9 juta perlintasan, WN China yang datang ke Indonesia sebanyak 1.401.443. Sedangkan WN China yang keluar dari Indonesia sebanyak 1.452 .249 orang. Kelahan preepsi terkait masuknya tenaga kerja asing bukan sepenuhnya terkait dengan kuantitasnya atau jumlahnya. Hal ini berkaitan dengan kedaulatan Indonesia sendiri yang tidak sepenuhnya mampu menampung pekerja dalam negeri di saat pengangguran dalam negeri makin meluas. Bahkan yang aneh pernyataan Jokowi bahwa "Hitungan kita 21.000 itu sangat kecil sekali. Jangan ditambahi nol terlalu banyak," Ucapan ini begitu memukul hati para penganguran yang didalam negeri. Poin utama adalah bukan terkait faktor utama tentang jumlahnya tetapi tentang kemampuan Negara dalam menyediakan lapamgan kerja bagi warganya. Memang betul pemerintah memiliki target mendatangkan turis dari China dengan jumlah 10 juta orang. Namun ternyata paspor wisata di ilegalkan untuk berbagai kegiatan di Indonesia. 


\section{Jurnal Ilmu Sosial Vol. 16 | No. 2 | Edisi Juli - Desember 2017|Hal.94-111}

Data yang dirilis oleh Dirjen Imigrasi RI sejak tahun 2015 Dirjen Imigrasi telah menerbitkan 2,895 juta paspor dengan 3810 izin tinggal untuk warga negara asing. Pada tahun 2015 terdapat 16.531 orang asing dengan pelanggaran kasus sebanyak 255 orang dan tahun 201658.838 dengan pelanggaran kasus sebanyak 264 yang biasanya deportasi. Melihat kenyataan pelanggaran imigrasi akibat kebijakan BVK yang menjadi ilegal oleh wisatawan terkait di beberapa tempat di Indonesia. Ada beberapa kasus yang berkaitan dengan TKA, seperti penangkapan 26 buruh ilegal dari Cina di Sukabumi karena diketahui menggunakan visa turis untuk bekerja sebagai buruh di PT Shanghai Electric Group.

Kasus lainnya adalah penangkapan terhadap TKA ketika mereka sedang melakukan pengeboran di lahan Bandara Halim Perdana Kusuma Jakarta. Di Kalimantan Barat, petugas imigrasi juga telah menangkap tenaga kerja asing Cina yang bekerja di CV Sari Pasifik Wood Factory, Kubu Raya. Kasus pelanggaran tenaga kerja asing juga terjadi di Kalimantan Tengah. Pada bulan April 2016, ada empat orang asing dari Cina yang masuk Kalimantan Tengah dan bekerja di Wilayah Pertambangan Rakyat (WPR) di Murungraya. Mereka telah ditangkap dan dideportasi oleh petugas imigrasi Palangkaraya. Di Maluku Utara, tenaga kerja asing juga telah menjadi masalah. Pada September 2016, jumlah tenaga kerja asing yang tercatat di Dinas Tenaga Kerja Maluku Utara mencapai 935 (databooks.com). Untuk warga negara yang dideportasi, hingga Agustus 2015 telah adalah 9.000 warga negara asing dengan 6.000 jenis pelanggaran.

Mengutip dari KOMPAS.com memberitakan Sebelas warga asing asal Tiongkok diamankan petugas Imigrasi Klas II Kota Singkawang di areal tambang zircon di Kecamatan Capkala, Kabupaten Bengkayang, Kalimantan Barat, Selasa (10/3/2015). Kepala Pengawasan dan Penindakan Keimigrasian (Wasdakim) Kantor Imigrasi Klas II Kota Singkawang, Jose Rizal mengatakan, sebelas warga negara asing tersebut bekerja di PT Megah Permata Karya Sukses yang bergerak dipertambangan zircon. Jose menjelaskan seharusnya para WNA itu menggunakan Kartu Izin Tinggal Terbatas (KITAS) jika ingin bekerja atau belajar. Namun, karena tidak menggunakan kartu itulah, para pekerja asal Tiongkok ini dianggap telah melanggar UU Keimigrasian. KITAS sendiri memiliki masa berlaku selama satu tahun dan bisa diperpanjang kembali jika sudah habis masa berlakunya.

Sedangkan mengutip TEMPO.co.id memberitakan bahwa Kantor Imigrasi Pekanbaru kembali memulangkan 19 tenaga kerja asal Cina yang bekerja di proyek Pembangunan PLTU, Tenayan Raya, Pekanbaru. Pekerja tersebut terbukti ilegal lantaran tidak memiliki visa bekerja. Setelah dilakukan pemeriksaan, ditemukan banyak tenaga kerja tidak memiliki visa bisnis sebagai dokumen resmi untuk bekerja. Mereka hanya memanfaatkan visa kunjungan untuk bekerja di PLTU Tenayan Raya, Pekanbaru. Para pekerja memanfaatkan 
Kartu Izin Tinggal Terbatas (Kitas) untuk bekerja. Modusnya, mereka akan kembali ke Cina setelah visa kunjungan habis masa berlakunya selama dua bulan kemudian akan kembali lagi setelah perpanjangan. Dilain sisi sudah terbentuk Tim Pemeriksa Imigrasi sebanyak 124 yakni 29 TPI bandar udara, 88 TPI Pelabuhan, serta 7 TPI lintas batas darat namun belum bisa maksimal menkan masukanya tenaga kerja asing yang masif sangat potensial menjadi ancaman potensi ancaman angkatan kerja generasi Indonesia. Sejumlah kasus di atas hanya sebagian kecil dari pelanggaran yang terjadi akibat mobilisasi masa melalui visa wisata yang di ilegalkan.

Menurut Barry Buzan. keamanan dapat dipahami dalam beberapa dimensi, yakni "the origin of threats" atau asal ancaman, "the nature of threats" atau sifat ancaman, "changing response"atau perubahan respons, "changing responsibility of security atau perubahan tanggungjawab keamanan, dan "values of security". Dimensi ini bisa di gunakan untuk menganalisis potensi anacaman tenaga kerja asiing. The origin of threats pada poin ini mewajibkan Negara memahami asal ancaman. Tenaga kerja asing bisa dipahami sebagai sumber ancaman. Dengan adanya tenga kerja asing memungkinkan terjadinya kompetisi dalam struktur konflik sosial di masyarakat. Kondisi ini berkaitan dengan ketersediaan lapangan kerja yang sempit namun di sisi lainya masuknya tenaga kerja asing merupakan saingan baru selain pekerja domestik. Akibatnya adalah kompetisi memungkinkan terjadinya struktur social di bawah pada tataran perubahan yang destruktif. Weber mengatakan bahwa konflik merupakan realitas sosial yang tidak bisa dihindarkan. Konflik merupakan bagian dari dinamika masyarakat menuju perubahan yang menandai struktur sosial berjalan. Lebih lanjut Galtung mengatakan bahwa Conflict is "a dynamic a process in which structure, attitudes and behavior are constanly changing and influencing one nother"(Anak Agung Banyu Parawita dan Nabila Sabban:2015:8-9). Galtung mengatakan konflik terjadi akibat adanya kontradiksi ( contradiction) yang dimana kontradiksi itu dipahami oleh berbedanya presepsi (attitude). Karena presepsi itulah melahirkan prilaku atau tindakan (behaviour). Melihat konteks TKA maka prilaku sosial digeser pada pola tersebut. Hal ini terkait dengan variabel ketersediaan lapangan kerja di daerah tersebut, apabila mencukupi maka ontologi konflik tidak akan berjalan pada tensi yang tinggi hanya sampai pada tingkat metode diskusi apabila terjadi kontradiksi.

Namun jika sebaliknya maka prilaku menuju pada pola desegregasi atau saling memaki dan destruktif. Mengambil salah satu TKA yaitu asal Tiongkok maka cenderung untuk mendekonstruksi Hal ini berkaitan dengan kisah masa lalu dimana Tiongkok di anggap sebagai bentuk imprealisme baru dalam penguasaan wilayah. Konflik kemudian diakselerasi dalam kepentingan politik sehingga polanya menuju pada perilaku 
"saya memaksa kamu melakukan apa yang saya mau". Dalam hal ini ada yang menjadi trager dalam isu TKA yaitu di mainkan oleh elit politik demi kepentingan kekuasaan. Dengan isu PKI, anti agama, dll, kemudian menjadi instrumen dalam pola konflik yang menjadi sumber kedua setelah kompetisi. Kenyataannya adalah Konfederasi Serikat Pekerja Indonesia (KSPI) melakukan demo untuk menuntut dikeluarkannya TKA China yang ada di Indonesia yang berjumlah 21 ribu orang yang melanggar Undang-undang Dasar (UUD) 1945 dan UU Ketenagakerjaan Nomor 13 Tahun 2003. Presiden KSPI, Said Iqbal mengatakan, keberadaan pekerja tak terampil asal China sudah meresahkan kaum buruh. Karena lapangan kerja yang seharusnya untuk warga negara Indonesia direbut oleh warga negara asing. Buruh kesal karena pemerintah selalu menyangkal keberadaan pekerja China. Mereka melayangkan gugatan di Jakarta mewakili 20 Provinsi ini paling lambat akhir Januari 2017 (liputan 6.com).

Kemudian, the nature of threats berhubungan dengan sifat ancaman. Dalam masalah ini ancaman sifatnya sangat masif, dalam arti setelah berlakunya BVK penyalagunaan terhadap BVK semakin masif dimana terjadi penyelewengan terhadap tujuan wisata menjadi tujuan kerja. Akibatnya terjadinya kompetisi yang anarkis dan membuat konstruksi sosial menjadi terganggu.

Variabel berikutnya changing response atau perubahan respons yaitu berhubungan dengan changing responsibility of security dalam hal ini pemerintah telah memperketat masuknya TKA dari Tiongkok dengan membuat Tim Pora dan memperketat ijin imigrasi. Walaupun pelanggaran imigrasi selalu bertambah namun pemerintah tetap fokus membenahi kebijakan agar kebijakan ini bukan menjadi celah untuk semakin banyaknya TKA illegal di Indonesia. Hal ini dijelaskan oleh Petugas Imigrasi bahwa orang China yang masuk hanya sekitar 8 juta lebih dan yang keluar melebihi 9 juta. Pada intinya bukan terkait pada jumlah masuk dan keluar namun jumlah TKA yang bekerja yang melanggar itulah yang menjadi masalah yaitu menggunakan visa Kunjungan Ijin Tinggal Sementara justru untuk bekerja di Indonesia. Poin terakhir adalah values of security, pada poin ini berhubungan dengan identitas, dan integritas. Identitas berhubungan dengan budaya, etnik, agama di struktur masyarakat yaitu NKRI. Sedangkan integritas berhubungan dengan kemampuan Negara dalam menyediakan lapangan kerja bagi warganya. Dalam arti bahwa hal ini berhubungan dengan kedaulatan Negara, gengsi, dan nama baik. Artinya ada kecenderungan bahwa mengapa Negara bisa menyediakan lapangan kerja bagi TKA sedangkan bagi warganya tidak mencukupi. Pola ini harus di pahami sebagai bentuk ancaman tenaga kerja domestik yang juga masih terlunta-lunta untuk mencari kerja. 
Oleh sebab itulah, dengan analisis ini diharapkan bisa menjadi preferensi untuk mengelola masalah ini lebih baik. Dalam arti jangan sampai struktur sosial terjadi kompetisi dan saling memaksa. Dengan demikian polanya harus pada "saya dan kamu melakukan sesuatu yang sesuatu yang menguntungkan buat kita berdua". Bila pola kerjasama ini terbentuk maka akan tercipta hubungan sosial yang transformatif. Pola solusinya adalah melibatkan semua pihak untuk membawa pola konflik ini melalui metode diskusi, baik dalam tingkat lokal, nasional dan bilateral antar negara.

\section{KESIMPULAN}

Berlakunya implementasi BVK merupakan peluang besar bagi Indonesia untuk menginternasionalisasi kepentingan pariwisata Indonesia di dunia internasional. Peluang tersebut dengan strategi memberikan akses khusus kepada 169 negara untuk berkunjung ke Indonesia. Target utamanya adalah menarik sebanyak mungkin wisatawan asing yang kondisi tersebut bisa berpengaruh pada akses pendapatan nasional. Dengan target 20 juta pengunjung dan menyerap tenaga kerja sebanyak 13 juta pekerja domestik disertai upaya meningkatkan tingkat kompetitif Indonesia dalam bidang pelayanan pariwisata adalah strategi kongkrit pemerintah untuk mengkapitalisasi sumberdaya produktif dalam bidang ekowisata. Kapitalisasi sektor pariwisata dengan sejumlah maksimalisasi BVK seperti Branding, Advertising, Selling adalah sejumlah langkah nyata pemerintah untuk menjadikan pariwisata sebagai sumber devisa nasional yang potensial. Perbaikan infrastruktur, kebijakan finansial, pembukaan wilayah "New Bali" disertai teknik $e$-diplomasi merupakan kombinasi antara kebijakan dan strategi implementasi.

Namun ternyata kebijakan BVK juga memicu kerentanan potensi ancaman keamanan non tradisional. Hal ini terjadi seperti masuknya TKA di Indonesia yang meningkat setiap tahunnya meningkat dan sampai tahun 2016 mencapai 70 ribu lebih. Kondisi ini menjadikan munculnya TKA bisa menjadi lahan bisnis ini sangat menggiurkan bagi sejumlah oknum. Dengan adanya kebijakan BVK justru akan menimbulkan mobilitas masuknya TKA ke Indonesia ke Indonesia. Sehingga, dengan analisis keamanan non tradisional bisa disimpulkan bahwa Indonesia memahami betul siapa yang menjadi ancaman yang bisa mengarah pada konflik di masyarakat. Oleh sebab itulah kebijakan BVK harus dikelola dengan baik, hal ini bukan hanya menjadi tanggung jawab imigrasi atas nama negara dan instansi lainnya namun kebijakan ini harus diawasi juga tidak merusak tatanan sosial di NKRI. 


\section{DAFTAR PUSTAKA}

Antariksa, Basuki, (2011). Analis Awal Masalah Kerjasama Internasional Dalam Pengurangan Dampak Perubahan Iklim Melalui Pariwisata, Jakarta: Pusat Penelitian dan Pengembangan Kementrian Kebudayaan dan Pariwisata:

Banyu Perwita, Anak Agung dan Muhamad Yani, Yanyan, (2005), Pengantar Studi Hubungan Internasional, Bndung: Remaja Rosdakarya.

Bayu , Arip Dkk , (2013). Jurnal Mina Laut Indonesia.Vol.1 No.1, Kendari: FPIK UNHALU.

Carlsnaes ,Walter, Dkk, (2013), Handbook Of International Relational trjmh , Nusamedia : Bandung,

Hakim , Cappy, (2011), Pertahanan Indonesia, Red \& White Publishing: Indonesia.

Haryanto, Sigit, (2016) Strategi Pemasaran Wisata Dengan Pendekatan, DOT, BAS dan POS, Kementrian Koordinator Bidang Maritim dan PUSHANKAM UPN"Veteran" Yogyakarta: Yogyakarta.

Kementrian Pariwisata dan Ekonomi Kreatif, (2015). Laporan Akuntanbilitas Kinerja Kementrian Pariwisata dan Ekonomi Kreatif, Jakarta: Kementrian Pariwisata dan Ekonomi Kreatif.

Laporan Kinerja Kementrian Pariwisata dan Ekonomi Kreatif Tahun (2014), Jakarta: Kementrian Pariwisata dan Ekonomi Kreatif.

May, Rudy T, (2002), Studi Strategis Dalam Transformasi Sistem Internasional Pasca Perang Dingin, PT.Rafika Aditama: Bandung.

Muhamad Fathun, Laode, (2016).Traansformasi Isu-Isu Hubungan Internasional Pasca Perang Dingin Di Era Globalisasi, Yogyakarta: Magister Hubungan Internasional. Universitas Muhammadiyah Yogyakarta.

Nurdin, Rachmad Angga, (2015), Keamanan Global, Bandung : Alfabeta.

Suprianto, Makmur, (2014), Tentang Ilmu Pertahanan, Jakarta: Yayasan Obor Indonesia. Asvaliantina, Velly, (2006). Dalam Seminar Digital Diplomacy. Jakarta: Deputi Bidang

Koordinasi Infrastruktur Kementrian Koordinator Bidang Kemaritiman. www.datacenter.bappedakaltim.com/data/pramusrenbangnasb/Multilateral\%20Plan\% 20Pariwisata.pdf, diakses pada 15 Oktober 2016 Pukul 20.18 WIB. Www.news.metrotvnews.com/read/2015/11/11/189909/lima-poin-kerja-sama-bidangpariwisata-indonesia-italia, diakses pada 15 Oktober 2016 Pukul 20.19 WIB. 
www.travel.detik.com/read/2016/11/16/182010/3347053/1382/indonesia-dan-singapura-

perkuat-kerjasama-di-bidang-pariwisata, diakses pada15 Oktober 2016 Pukul 20.28 WIB.

www.imigrasi.go.id/index.php/berita/berita-utama/1151-imigrasi-kini-waspadai-agen-travelabal-abal, diakses pada 15 Oktober 2016 Pukul 20.30 WIB.

www.imigrasi.go.id/index.php/en/berita/berita-utama/816-bebas-visa-jumlah-wna-di-indonesiabertambah, diakses pada 15 Oktober 2016 Pukul 20.35 WIB.

news.detik.com/berita/d-3379674/menaker-hanif-dhakiri-tka-ilegal-ada-tapi-isu-tka-china-itupolitis, diakses pada 15 Oktober 2016 Pukul 20.38 WIB.

www.nasional.kompas.com/read/2016/12/24/14435601/

dirjen.imigrasi.ungkap.data.wn.china.yang.keluar-masuk.indonesia, diakses pada 15 Oktober 2016 Pukul 20.48 WIB.

www.m.tempo.co/read/news/2017/02/23/063849375/imigrasi-pekanbaru-deportasi-19-tenagakerja-asal-cina, diakses pada 15 Oktober 2016 Pukul 20.50 WIB.

www.bisnis.liputan6.com/read/2784454/protes-serbuan-pekerja-china-buruh-bakal-demo, diakses pada 15 Oktober 2016 Pukul 20.52 WIB. 